\title{
Pengembangan Sumber Daya Manusia Untuk Suksesi Program Full Day School Di Madrasah Ibtidaiyah Al-Azhary Ajibarang Banyumas
}

\author{
Suwito $^{1}$, Henie Kurniawati ${ }^{2}$, Ahmad Sahnan ${ }^{3 *}$ \\ IAIN Purwokerto \\ 1e-mail: suwitons@iainpurwokerto.ac.id \\ ${ }^{2}$ e-mail: henie@iainpurwokerto.ac.id \\ 3e-mail: sahnan@iainpurwokerto.ac.id \\ *Corresponding Author
}

\begin{abstract}
ABSTRAK
Madrasah Ibtidaiyah Al-Azhary adalah sekolah yang mampu menerapkan program full day school dengan baik sehingga mengantarkan ia menjadi sebuah lembaga favorit di Kab. Banyumas. Akan tetapi dibalik keunggulan-Nya MI ini memiliki sisi kekurangan di bidang SDM. Adapun kegiatan Pengabdian ini bertujuan untuk memberikan pengetahuan secara teoritis dan mengembangkan mutu sumber daya manusia. Program ini dilaksanakan dalam bentuk workshop melalui pendekatan andragogik. Adapun hasil yang dicapai dari pengabdian ini. Pertama, peserta workshop memiliki pengetahuan tentang posisi sebagai pendidik berdasarkan karakteristik anak sehingga muncul hubungan positif antara guru dan anak. Kedua, guru mendapatkan pengalaman dan wawasan tentang strategi pembelajaran aktif lagi menyenangkan sehingga terjadi proses belajar mengajar yang aktif dan menyenangkan diantara siswa dan guru. Ketiga, melalui program full day school dengan proses pembelajaran aktif dapat membentuk karakter siswa. Keempat, peserta menyadari bahwa program kegiatan pengabdian dalam bentuk workshop merupakan hal yang harus dilakukan secara kontinyu demi tercapainya sumber daya manusia yang baik.
\end{abstract}

Kata Kunci: Full Day School, Madrasah Ibtidaiyah, Sumber Daya Manusia

\begin{abstract}
Madrasah Ibtidaiyah Al-Azhary is a school that is able to implement a full-day school program so well that it makes it a favorite school Banyumas. However, behind these advantages, this school has shortcomings in the HR field. The Community Service activities are intended to provide knowledge and support human resources. This program is carried out in the form of a workshop through discussing andragogy. From the results of this dedication. first, participants have knowledge about the position as educators based on the characteristics of the child so that a positive relationship exists between the teacher and student. Second, the teacher gets experience and insights about active learning strategies that are more fun so that an active and fun learning process occurs between students and teachers. Third, through a full day school program with an active learning process can shape the character of students. Fourth, participants realize that the program of service activities in the form of workshops is something that must be use continuously in order to achieve good human resources.
\end{abstract}

Keywords: Full day School, Islamic Primary School, Human Resources 


\section{PENDAHULUAN}

Tahun 2017 Menteri pendidikan dan Kebudayaan mewacanakan implementasi program full day school untuk peserta didik SD dan SMP. Program full day school dinilai relevan oleh menteri pendidikan dan Kebudayaan dalam membentuk karakter peserta didik di era globalisasi yang semakin maju.(Winurini, 2016) Program ini juga dinilai dapat menjawab tuntutan para orang tua yang menginginkan anak-anaknya mendapat prestasi akademik yang baik, serta mengantisipasi terlibatnya anak mereka terhadap masalah-masalah kemajuan zaman dan teknologi yang semakin tak terbendung.(Tamba, Manalu, Laurensia, \& Kariani, 2019)

Full day school merupakan hasil dari pemikiran para praktisi pendidikan demi terkontrolnya anak-anak di luar jam formal sekolah. Sismanto mengartikan full day school ini sebagai model sekolah umum dengan memadukan sistem pembelajaran Islam yaitu memberikan tambahan waktu untuk pendalaman keagamaan peserta didik.(Syafrida, 2017) Konsep full day school ini belajar dengan waktu yang lebih lama jika dibandingkan dengan sekolah lainnya. Konsep ini akan menjadikan interaksi guru dengan peserta didik lebih banyak sehingga pembelajaran lebih intensif. Program ini akan memberikan kesempatan lebih banyak lagi kepada peserta didik dalam memperbaiki setiap program pembelajaran yang dinilai masih kurang maksimal sebagaimana tujuan pendidikan ditetapkan. Full day school dilakukan dengan aktivitasaktivitas yang beraneka ragam melalui penambahan jam belajar serta cara untuk meningkatkan kualitas pendidikan yang masih minim.(Baharun \& Alawiyah, 2018)

Berdasarkan riset yang telah dilakukan oleh Siswadi pada tahun 2018 dengan judul "model manajemen kurikulum pada program full day school di Madrasah Ibtidaiyah (MI) al-Azhary Ajibarang”, Ia mengungkapkan bahwa MI ini menerapkan program full day school. Terhitung sejak tahun 2009 MI al-Azhary sudah menerapkan program full day school. Hingga saat ini MI tersebut merupakan satu-satunya MI yang dapat melaksanakan program full day school di kabupaten Banyumas. MI al-Azhary menjadi MI favorit bagi masyarakat kecamatan Ajibarang dan sekitarnya. MI ini mampu mengintegrasikan kelompok mata pelajaran umum dan agama. Hal itu menjadikan MI al-Azhary memiliki peran yang baik dalam membentuk karakter peserta didik.

MI al-Azhary kecamatan Ajibarang kabupaten Banyumas merupakan sekolah tingkat pertama berbasis agama yang sederajat dengan Sekolah Dasar (SD). MI tersebut menjadi pilihan masyarakat sekitar untuk menempa generasi muda agar memiliki karakter agamis dan dapat menyesuaikan diri dengan kemajuan zaman. Dengan kata lain, alasan masyarakat menyekolahkan putra-putrinya di MI al-Azhary kecamatan Ajibarang kabupaten Banyumas ialah agar anaknya memiliki pengetahuan tentang ilmu agama dan ilmu umum. 
MI al-Azhary Ajibarang kabupaten Banyumas merupakan sekolah dengan akreditasi A. Akreditasi tersebut diperoleh madrasah pada tahun 2015 dengan nilai “90". MI al-Azhary Ajibarang kabupaten Banyumas adalah sekolah yang beralamat di Jalan Pancurendang Nomor 15 RT 02 RW 04 Desa Lesmana kecamatan Ajibarang kabupaten Banyumas propinsi Jawa Tengah Kode Pos 53163, email: mi.alazhary@gmail.com, website: www.mialazhary.sch.id, Telphone (0281) 571491, HP. 082326711193. MI al-Azhary Ajibarang kabupaten Banyumas merupakan madrasah yang berada di bawah naungan Yayasan Aji Yumika. Yayasan Aji Yumika beralamatkan di Grumbul Karangcengis Desa Lesmana Kecamatan Ajibarang Kabupaten Banyumas Provisni Jawa Tengah.

Melalui informasi dari penelitian Siswadi disampaikan bahwa keunggulan yang dimiliki oleh MI al-Azhary Ajibarang masih memiliki kekurangan terutama di bidang SDM (sumber daya manusia). Adapun kelemahan yang dimaksud antara lain: (1) Guru belum mampu sepenuhnya mengimplementasikan program full day school (2) Minimnya penguasaan guru dalam pengimplementasian pembelajaran. (3) Kurang siapnya guru menjadi fasilitator dalam kegiatankegiatan keagamaan. (4) Minimnya pelatihan dan peningkatan skill dalam program full day school. (5) Minimnya penguasaan tahapan yang mesti dilalui dalam pelaksanaan program full day school (6) Minimnya penguasaan metode pembelajaran khsususnya dalam pembelajaran agama. (7) Belum mampu sepenuhnya mengelola waktu dengan bijak.

Berdasarkan kelemahan tersebut maka dilakukan kegiatan pengabdian masyarakat dengan memberikan pelatihan pada guru di MI al-Azhary Ajibarang agar mereka memiliki kemampuan untuk mengatasi berbagai kelemahan yang ada. Jadi tujuan dari dilakukannya kegiatan pengabdian ini untuk transfer knowledges dengan memberikan workshop pemahaman, pendampingan dan simulasi tentang pematangan mutu SDM.

\section{BAHAN DAN METODE}

Kegiatan pengabdian ini dilakukan melalui pendekatan andragogik sasaran orang dewasa, yaitu model pendidikan melalui pengabdian kepada masyarakat yang pesertanya orang dewasa. Program pengabdian ini dilaksanakan pada bulan September (semester gasal) tahun ajaran 2019/2020 mengacu pada kalender akademik kampus IAIN Purwokerto.

Kegiatan program pengabdian dilaksanakan melalui strategi kemitraan. Dalam hal ini tim peneliti/pengabdi berperan sebagai narasumber, bekerjasama dengan pihak mitra kepala sekolah dan wakil kepala sekolah. Tim sebagai fasilitator mempunyai tanggung jawab untuk menyiapkan materi-materi dan bahan-bahan yang akan dipresentasikan dalam pengabdian serta bahan-bahan dalam penunjang tersampaikannya materi. Sementara itu pihak sekolah memiliki tugas dan 
tanggung jawab untuk menyediakan tempat dan mengundang para guru untuk dapat menghadiri program workshop. Lebih jelasnya program ini dilaksanakan melalui tahapan-tahapan berikut:

1. Persiapan pengabdian; dalam hal ini menyiapkan surat izin melakukan pengabdian dari pihak kampus (wakil dekan I FTIK IAIN Purwokerto). Persiapan pengabdian ini juga dalam bentuk materi dan bahan-bahan yang menjadi pendukung dalam pelaksanaan pengabdian. Selanjutnya menyampaikan ke pihak sekolah MI al-Azhary Ajibarang untuk kemudian ditindaklanjuti. Pihak sekolah merespon dengan baik dan akan menyampaikan ke guru-guru, kemudian membuat kesepakatan bersama terkait waktu dan tanggal pelaksanaan pengabdian.

2. Realisasi program; setelah semua perlengkapan beres begitupun dengan pihak mitra sudah menentukan waktu dan tanggal maka program workshop active learning dalam mengembangkan SDM guru-guru MI al-Azhary dilaksanakan yaitu pada bulan September 2019. Pada bagian ini akan dilaksanakan bentuk workshop yang dalam hal ini materi disampaikan tentang psikologi pendidikan, active learning, memberikan percontohan langsung dalam bentuk praktik.

3. Monitoring dan evaluasi kegiatan; kegiatan ini dilakukan pasca program workshop. Tim pengabdi melakukan evaluasi dengan melihat hasil worksheet dari peserta workshop apakah program sudah sesuai sebagaimana yang diharapkan. Disamping itu tim juga menawarkan konsultasi selama pelaksanaan program dan setelah pelaksanaan acara melalui sosial media sekaligus bentuk monitoring.

4. Penyusunan laporan pengabdian; setelah semua program pengabdian selesai tim pengabdi menyusun kegiatan dalam bentuk laporan. Laporan ini dituliskan dalam bentuk diskriftif yang kemudian nanti sebagai bukti dan presentasi di kampus dan selanjutnya di publikasikan.

5. Penyerahan laporan akhir (selesai); setelah laporan selesai akan dibagikan kepada kampus dan pihak mitra sebagai pedoman bersama. Selanjutnya hasil dari pengabdian ini di publikasikan dalam bentuk jurnal.

Tabel 1. Matrik Kegiatan Pengabdian

\begin{tabular}{clcccccc}
\hline No & \multicolumn{1}{c}{ Uraian kegiatan } & $\mathbf{1}$ & $\mathbf{2}$ & $\mathbf{3}$ & $\mathbf{4}$ & $\mathbf{5}$ & $\mathbf{6}$ \\
\hline 1 & Persiapan pengabdian & $\checkmark$ & $\checkmark$ & & & & \\
2 & Realisasi Program & & $\checkmark$ & $\checkmark$ & $\checkmark$ & $\checkmark$ & \\
3 & Monitoring dan Evaluasi kegiatan & & & & & $\checkmark$ & \\
4 & Penyusunan laporan pengabdian & & & & & $\checkmark$ & $\checkmark$ \\
5 & Penyerahan laporan akhir (selesai) & & & & & & $\checkmark$ \\
\hline
\end{tabular}

Sumber: Data Primer, 2019 


\section{HASIL DAN PEMBAHASAN}

Kegiatan program pengabdian kepada masyarakat ini dilakukan di MI al-Azhary Ajibarang Kabupaten Banyumas. Materi yang disampaikan oleh tiga narasumber tersebut memiliki integrasi antara satu dengan yang lainnya. Pertama materi disampaikan oleh Suwito dengan tema tema filosofi mengajar materi ini menjelaskan bagaimana seharusnya guru dalam melaksanakan pembelajaran harus menarik dan berkarakter. Seorang guru harus dituntut menjadi guru yang interaktif dan aktif. Guru harus mampu mengembangkan potensi setiap peserta didik ke arah yang lebih baik. Selama ini guru dominan menggunakan metode ceramah, padahal secara teori menggunakan metode ceramah materi yang disampaikan akan mudah dilupakan oleh siswa.

Materi selanjutnya disampakan oleh Henie tentang psikologi pendidikan. Materi ini berisi tentang bagaimana menjadi seorang guru yang menarik dari persfektif psikologi. The power of great teacher dapat terbentuk dengan memperkenalkan beberapa strategi kepada siswa, memberikan praktek tugas yang beragam, pentingnya guru sebagai model, mendorong peserta didik dengan berbagai strategi, feedback, trasnfer pengetahuan, latihan, mempertahankan motivasi siswa, refleksi, dan merencanakan. Henie juga menekankan pentingnya the power of smile berusaha selalu berfikir positif, sebisa mungkin hindari kata "jangan, kamu" sebaiknya kita gunakan kata "kita". Materi selanjutnya tentang multiple inteligens bahwa setiap anak memiliki kecerdasan yang berbeda.

Materi ketiga diisi oleh Ahmad Sahnan yaitu tentang bagaimana pembelajaran di MI. Anak-anak SD/MI merupakan anak yang ada pada masa keemasan. Setiap anak memiliki potensi yang berbeda-beda. Peserta didik bukanlah gelas kosong yang hanya diisi air begitu saja. Proses pembelajaran idealnya diselenggarakan dengan menyenangkan. Untuk menghindari kebosanan anak dalam proses pembelajaran bisa kita menggunakan ice breaking biar anak fresh kembali.

Pada bagian terakhir ketiga narasumber sama-sama terlibat melaksanakan workshop active learning untuk mengembangkan mutu SDM dalam program full day school. Tema tentang active leraning disampaikan mulai dari paradigma sampai ke praktek langsung. Materi yang disampaikan antara lain: the power of two, Index card match, index card short, card sort, every one is a teacher here, google class dan lain-lain.

Kegiatan pengabdian ini diikuti oleh semua guru termasuk kepala madrasah dan wakil kepala madrasah. Guru-guru mengikuti proses pengabdian ini dengan baik mulai dari awal. Kegiatan dimulai dari pagi hingga sore hari. Pada proses workshop ini narasumber memanfaatkan media yang ada dengan beraneka ragam metode (dynamic lecturing) dengan menggunakan media LCD dan media yang ada dalam ruangan. 
Selama worskhop berlangsung peserta mengikuti dengan serius, semangat dan antusias. Ini tercermin dari wajah mereka yang senang dan penuh serius ketika pemateri menyampaikan materinya. Dalam pelaksanaan workshop ini para peserta juga bertanya tentang materi yang disampaikan sebagai bentuk keseriusan mereka. Tim pelaksana workshop juga dalam keadaan fun, serius dan santai sehingga peserta merasa senang dan tidak boring. Pada sela-sela workshop tim juga melaksanakan ice breaking agar peserta tetap fokus dan me-refresh kembali jika kira-kira sudah mulai jenuh. Sehingga proses kegiatan workshop ini berjalan dengan lancar.

Secara keseluruhan kegiatan workshop active learning yang bertujuan meningkatkan sumber daya manusia di MI al-Azhary berjalan dengan baik. Ini terlihat dari pengakuan dan respon langsung dari peserta. Pada akhir acara sebelum penutupan dari pihak tim meminta kesan dari setiap peserta. Seluruh peserta memberikan respon positif termasuk kepala sekolah. Sebagian guru lainnya menyampaikan secara jujur bahwa workshop ini adalah baru dan merasa senang dapat pengetahuan baru. Begitupun dengan guru-guru yang lain baik bidang umum maupun agama merasa senang karena nanti ilmu ini akan diterapkan ketika melakukan pembelajaran. Ada juga yang menyampaikan sebelum mendapatkan workshop ini guru bingung mau menggunakan metode apa karena guru tersebut melihat anak didiknya kesannya bosan dengan metode yang selalu dia gunakan mengingat sekolah ini adalah full day school.
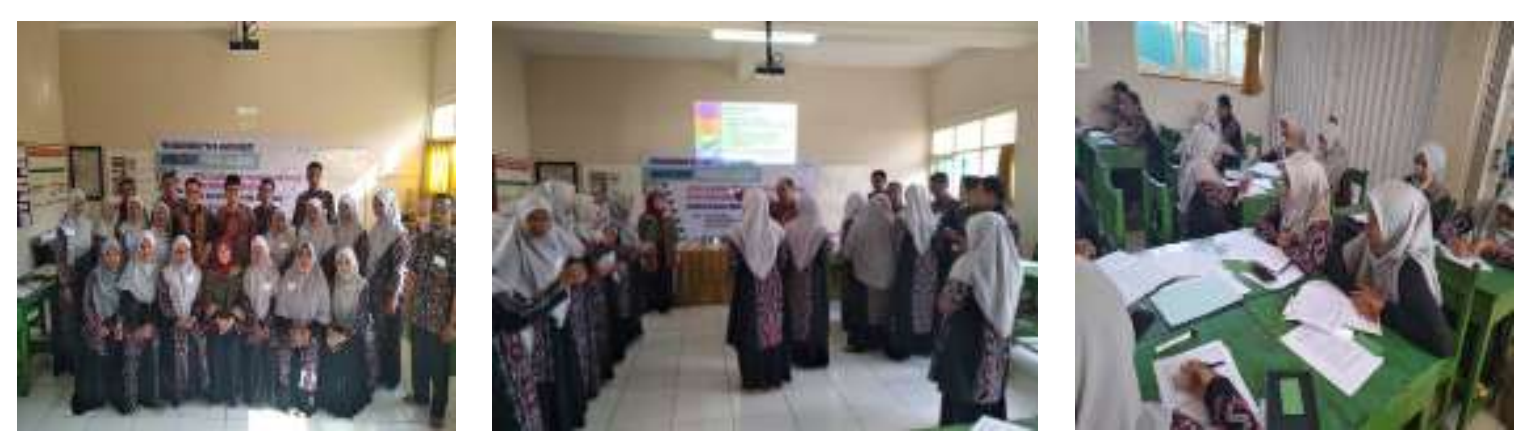

Gambar 1. Pelaksanaan workshop Active Learning 14-09-2019

Kegiatan implementasi program full day school melalui active learning dengan tujuan mengembangkan mutu SDM guru-guru MI al-Azhary Ajibarang ini terdiri dari 20 orang guru/SDM. Guru laki-laki sejumlah 5 orang (25\%) dan guru perempuan sejumlah 15 orang (75\%). Rincian data SDM peserta wokhshop terdapat pada Tabel 2. 
Tabel 2. Rincian Data SDM Berdasarkan Jenis Kelamin

\begin{tabular}{lll}
\hline Guru/SDM & Jumlah & Prosentase \\
\hline Laki-laki & 5 & $25 \%$ \\
Perempuan & 15 & $75 \%$ \\
\hline \multicolumn{2}{c}{ Sumber: Data Primer, 2019}
\end{tabular}

SDM terdiri dari kepala madrasah, wakil kepala madrasah, guru mata pelajaran (mapel) kelas I sampai dengan kelas VI serta guru sebagai wali kelas. Workhsop dilakukan untuk meningkatkan mutu dan kompetensi SDM, serta meminimalisir permasalahan mitra dalam hal ini MI Al Azhary Ajibarang sehingga guru mampu sepenuhnya mengimplementasikan program full day school dalam pembelajaran, kesiapan guru menjadi fasilitator dalam kegiatan-kegiatan keagamaan, serta aktif mengikuti pelatihan dan peningkatan skill dalam program full day school.

Materi workshop dilakukan untuk meningkatkan penguasaan tahapan yang mesti dilalui dalam pelaksanaan full day school, penguasaan metode pembelajaran khsususnya dalam pembelajaran agama, serta pelatihan terkait proses pembelajaran yang mengacu pada program full day school secara integrative dan terpadu melibatkan skill psiko sosial edukatif dan spiritual. Rekapitulasi respon SDM dalam realisasi program dan monitoring evaluasi kegiatan terdapat dalam tabel 3.

Tabel 3. Rekapitulasi Hasil Kegiatan

\begin{tabular}{|c|c|c|c|c|c|c|c|c|c|}
\hline \multirow[t]{3}{*}{ Realisasi Program Kegiatan } & \multicolumn{9}{|c|}{ Monitoring Evaluasi SDM } \\
\hline & \multicolumn{3}{|c|}{$\begin{array}{l}\text { Readiness } \\
\text { (Kesiapan) }\end{array}$} & \multicolumn{3}{|c|}{$\begin{array}{l}\text { Support } \\
\text { (Dukungan) }\end{array}$} & \multicolumn{3}{|c|}{$\begin{array}{l}\text { Implementation } \\
\text { (Penerapan) }\end{array}$} \\
\hline & KB & $\mathrm{CB}$ & B & KB & $\mathrm{CB}$ & B & KB & $\mathrm{CB}$ & $\mathrm{B}$ \\
\hline $\begin{array}{l}\text { Materi I } \\
\text { (Utama) }\end{array}$ & $\begin{array}{l}0 \\
(0 \%)\end{array}$ & $\begin{array}{l}3 \\
(15 \%)\end{array}$ & $\begin{array}{l}17 \\
(85 \%)\end{array}$ & $\begin{array}{l}0 \\
(0 \%)\end{array}$ & $\begin{array}{l}4 \\
(20 \%)\end{array}$ & $\begin{array}{l}16 \\
(80 \%)\end{array}$ & $\begin{array}{l}0 \\
(0 \%)\end{array}$ & $\begin{array}{l}2 \\
(10 \%)\end{array}$ & $\begin{array}{l}18 \\
(90 \%)\end{array}$ \\
\hline Active Learning & & & & & & & & & \\
\hline $\begin{array}{l}\text { Materi II } \\
\text { (Pendukung) }\end{array}$ & $\begin{array}{l}0 \\
(0 \%)\end{array}$ & $\begin{array}{l}4 \\
(20 \%)\end{array}$ & $\begin{array}{l}16 \\
(80 \%)\end{array}$ & $\begin{array}{l}0 \\
(0 \%)\end{array}$ & $\begin{array}{l}3 \\
(15 \%)\end{array}$ & $\begin{array}{l}17 \\
(85 \%)\end{array}$ & $\begin{array}{l}0 \\
(0 \%)\end{array}$ & $\begin{array}{l}3 \\
(15 \%)\end{array}$ & $\begin{array}{l}17 \\
(85 \%)\end{array}$ \\
\hline Karakter SDM & & & & & & & & & \\
\hline $\begin{array}{l}\text { Materi III } \\
\text { (Pendukung) }\end{array}$ & $\begin{array}{l}0 \\
(0 \%)\end{array}$ & $\begin{array}{l}10 \\
(50 \%)\end{array}$ & $\begin{array}{l}10 \\
(50 \%)\end{array}$ & $\begin{array}{l}0 \\
(0 \%)\end{array}$ & $\begin{array}{l}12 \\
(60 \%)\end{array}$ & $\begin{array}{l}8 \\
(40 \%)\end{array}$ & $\begin{array}{l}0 \\
(0 \%)\end{array}$ & $\begin{array}{l}14 \\
(70 \%)\end{array}$ & $\begin{array}{l}6 \\
(30 \%)\end{array}$ \\
\hline
\end{tabular}

Keterangan :

Kategori : KB: Kurang Baik; CB : Cukup Baik, B: Baik

Sumber: Data Primer, 2019

Berdasarkan rekapitulasi respon peserta menunjukkan hasil tentang kesiapan kategori baik menerima materi I sebesar 85\%, materi II sebesar $80 \%$ dan materi III sebesar $50 \%$. Hasil tentang dukungan kategori baik terhadap materi 1 sebesar $80 \%$, materi II sebesar 85\%, materi III sebesar $40 \%$. Hasil tentang penerapan kategori baik dalam merespon materi I sebsesar $90 \%$, materi II 85\%, dan materi III sebesar $30 \%$. Hasil tersebut mengindikasikan bahwa peserta cukup siap, 
mendukung dan menerapkan dalam merespon materi I dan materi II, sedangkan kesiapan, dukungan dan penerapan materi III peserta merespon dengan cukup baik.

Suksesnya program ini disebabkan adanya kerjasama yang baik dari tim pengabdi dengan pihak MI. Kesadaran guru-guru akan pentingnya pelaksaan workshop dalam bentuk pembelajaran merupakan faktor penunjang terealisasikannya kegiatan workshop ini. Adapun sedikit penghambatnya tentang waktu yang tidak cukup, menetapkan waktu yang yang pas antara tim pengabdi dan pihak sekolah, mengingat tim pengabdi juga mengajar di kampus. Begitu juga dengan madrasah yang menerapkan program full day school awalnya berencana setelah selesai jam pembelajaran tetapi guru-guru sudah kelelahan di sore hari mengingat mereka juga harus pulang ke keluarganya masing-masing. Acara ini dilaksanakan hari sabtu seharian penuh. Kemudian yang semula rencana kegiatan ini dilaksanakan bulan Agustus namun pihak sekolah meminta bulan September dikarenakan bulan Agustus digunakan untuk melakukan persiapan kegiatan agustusan dan sekolah mengadakan rihlah Ilmiah. Meskipun ada hambatan-hambatan namun program ini berjalan dengan lancar dengan komunikasi yang baik serta pemanfaatan media sosial.

\section{PEMBAHASAN}

Mutu sering diartikan sebagai kualitas, baik, benar, memiliki standar atau kualitas yang tinggi. Jika dikaitkan dengan pendidikan mutu dapat diartikan pemberian pengalaman belajar yang baik terhadap peserta didiknya.(Ju`subaidi, 2012) Awalnya peningkatan mutu lebih sering digunakan di bidang perusahaan namun era kontemporer ini istilah mutu digunakan dalam dunia pendidikan. Mutu dalam pendidikan mengarah kepada masukan, proses, luaran dan dampaknya. Artinya baik atau tidaknya SDM nya, prasarana, visi misi, dan sebagainya.(Rahman, Ardiansyah, \& Marwazi, 2015)

Untuk meningkatkan mutu dalam sebuah perusahaan maka pelatihan dan pengembangan sumber daya manusia adalah bagian terpenting di dalamnya. Patrick menegaskan bahwa pengembangan sumber daya manusia ialah pengembangan pengetahuan, ketrampilan dan keahlian yang diinginkan seseorang untuk menjalankan tugasnya secara efektif. Bartel menambahkan dalam pengembangan harus ada program pelatihan dan pertumbuhan produktivitas. Dalam konteks pemerintahan maupun untuk pengembangan ini bisa dilakukan melalui pendidikan dan pelatihan. Sebab pendidikan dan pelatihan dianggap sebagai bagian integral dalam mengembangkan produktivitas dan ketrampilan pegawai.(Kalangi, 2015)

Pengembangan Mutu SDM (sumber daya manusia) merupakan suatu keharusan dilaksanakan dalam madrasah. Sebab untuk menngembangkan mutu/kualitas yang baik dengan 
adanya pelaksanaan program pelatihan atau pendidikan. Pelatihan dalam bentuk workshop ini bertujuan untuk meningkatkan profesionalisme, kemampuan, ketrampilan, keahlian sumber daya manusia agar semakin tumbuh lebih baik dari sebelumnya sehingga menjadi pribadi yang dapat melaksanakan tugasnya dengan optimal dan efektif, dan menjadi pribadi yang memiliki moral yang baik, mengembangkan kemampuan kognitif, afektif dan psikomotorik seseorang.

Salah satu program workshop yang diyakini dapat mengembangkan mutu SDM ialah melalui program workshop active learning. Sebab pembelajaran aktif tidak hanya siswa, guru juga dituntut agar senantiasa aktif ketika melaksanakan program pembelajaran. selanjutnya melihat permasalahan mitra dalam hal ini dalam proses pembelajaran dalam program full day school aktifitas sekolah belajar seharian penuh. Untuk menghindari kebosanan dan agar proses pembelajaran senantiasa berjalan dengan baik maka perlu adanya pembelajaran aktif.

Pembelajaran aktif ialah segala bentuk pembelajaran yang bisa membuat peserta didik. Peserta didik dapat mengaktualisasikan dirinya secara aktif dalam proses pembelajaran baik itu terhadap dirinya, teman, dan gurunya.(Yetti, 2016) Pembelajaran aktif merupakan proses belajar yang titik tekannya pada aspek fisik, mental, emosi serta intelektual peserta didik agar tercapai tujuan pendidikan yang berkaitan dengan aspek kognitif, afektif dan psikomotorik.(Murti, 2016) Pembelajaran aktif adalah belajar yang meliputi berbagai cara untuk membuat siswa aktif sejak awal melalui aktivitas-aktivitas yang membangun kerja kelompok dan dalam waktu singkat membuat mereka berfikir tentang materi pelajaran.(Silbermen, 2014)

Pembelajaran dapat berlangsung efektif manakala dalam suatu proses yang terjalin komunikasi yang aktif antara guru dan siswa dengan melibatkan aspek intelektual dan emosional. Dengan demikian, dapat dikatakan bahwa pembelajaran aktif adalah proses keterlibatan intelektual dan emosional peserta didik dalam proses belajar mengajar yang dapat memungkinkan terjadinya: (1) Proses asimilasi dan akomodasi dalam pencapaian pengetahuan; (2) Proses perbuatan serta pengalaman langsung terhadap umpan balik dalam pembentukan keterampilan; dan (3) Proses penghayatan serta internalisasi nilai-nilai dalam rangka pembentukan nilai dan sikap.(Sunaryo, 2017)

Active Learning merupakan metode pembelajaran yang memberi kesempatan terhadap peserta didik agar dapat berperan aktif selama proses pembelajaran. Pembelajaran aktif secara tidak langsung akan mengajak peserta didik turut serta dalam semua proses pembelajaran, baik itu secara fisik maupun secara mental sehingga siswa dapat menguasai materi pelajaran yang disampaikan dengan baik.(Kusumawati, 2017)

Secara keseluruhan program workshop untuk mengembangkan SDM (Sumber daya manusia) di MI al-Azhary Ajibarang melalui pembelajaran active learning berhasil dengan baik. 
Program ini membantu mitra sekolah dalam menemukan solusi yang sebelumnya merasa kesulitan akan program pembelajaran mengingat sekolah ini menerapkan program full day school. Melalui program ini sekolah terbantu melalui program workshop ini. manfaatnya guru-guru dapat pengetahuan dan memiliki beraneka ragam metode pembelajaran sehingga materi dan proses pembelajaran akan berjalan dengan efektif. Pada gilirannya siswa akan belajar dengan semangat dan tidak akan merasakan kejenuhan dan ini akan menunjang prestasi akademik siswa.

Pendidikan dengan menerapkan full day school membutuhkan SDM yang berkarakter, kreatif dalam memberikan metode pembelajaran, dan mampu menggunakan teknologi/IT yang handal dan bermutu. Kreativitas merupakan suatu proses yang tidak hanya melibatkan faktor kognitif semata, seperti pemecahan masalah, italic tetapi juga melibatkan kualitas personal individu seperti karakteristik sosial dan emosional pendidikan di keluarga dan masyarakat, konteks sosial dan kultural dan lain-lain.(Kobert, 1999)

Kreativitas haruslah memiliki nilai novelty, namun tidak hanya sekedar baru. Sesuatu yang kreatif itu juga harus mampu menjawab persoalan dan berdaya guna. Novelty (kebaruan) dari suatu hal yang kreatif itu bisa dilihat dari dua sisi. Dari sisi individu dan dari sisi orang lain, Untuk mencapai pemikiran yang kreatif, terjadi proses-proses melalui beberapa tahapan. Ada banyak ahli yang mengemukakan tentang tahap dan proses dalam kreativitas dalam pendidikan FDS (Full Day School) dan peningkatan mutu SDMnya. Salah satunya seperti yang dikemukakan oleh Amabile.(Robert, 2006) Menurut Amabile proses kreativitas melalui 5 tahap yang dilalui oleh individu secara bervariasi, 5 tahap tersebut adalah :

\section{Problem or task identification}

Proses kreatif dimulai ketika individu menyadari adanya suatu masalah, baik yang ditimbulkan dari dalam dirinya (gejolak emosionalnya) maupun yang datang dari luar dirinya (tugas-tugas).

\section{Preparation}

Individu mengaktifkan ingatannya mengenai informasi-informasi yang relevan atau yang dapat diterapkan untuk memecahkan masalah, termasuk algoritma / pemikiran analitis yang dibutuhkan. Untuk mendapatkan outcome yang kreatif, individu harus meninggalkan pemikiran analitisnya dan menggunakan heuristic, yang memungkinkannya menerapkan metode baru menghadapi masalahnya

3. Response generation

Informasi yang diingat dan yang diperoleh dari lingkungan digunakan sebagai dasar dari alternatif solusi terhadap masalah 


\section{Response validaton and communication}

Pada tahap ini individu mengevaluasi alternatif solusi yang dimilikinya, positif dan negatifnya yang menjadi dasar pengambilan keputusan, solusi mana yang akan dipakai untuk menjawab permasalahan.

\section{Outcome}

Hasil yang diperoleh setelah individu menerapkan solusi yang dipilihnya, apakah berhasil menjawab permasalahan, menjawab sebagian masalah atau tidak sama sekali, sehingga individu memutuskan untuk me-mikirkan ulang pemecahannya atau menyerah.

Proses dan tahap yang dikemukakan oleh Amabile ini disebut componential model of creativity. Selanjutnya tahap dan proses kreatifitas melewati 5 tahap yaitu :

1. Preparation: tahap persiapan, mengidentifikasi masalah, memahami masalah dan mengumpulkan informasi yang berkaitan.

2. Incubation: tahap ini sering disebut waktu istirahat (time-off) individu berhenti sejenak dari konsentrasi terhadap masalah, mengedapkan pemikiran-pmikiran yang sudah terbentuk sebelumnya.

3. Illumination: insight atau Aha! terjadi pada tahap ini, dimana individu tiba-tiba tersadar atau mendapat inspirasi tentang pemecahan masalahnya.

4. Evaluation: hasil pemikirannya dievaluasi, dinilai kemungkinan pelaksanaannya, keuntungan dan kerugian yang dihasilkannya

5. Revision: perbaikan atas solusi yang dibuat apabila pilihan tersebut tidak berhasil memecahkan masalah

Lingkungan pendidikan dan sosial mempengaruhi task motivation individu. Individu akan lebih kreatif ketika dia memiliki motivasi intrinsik, daripada ketika dia memiliki motivasi ekstrinsik. Hal itu dapat dicontohkan dengan seorang pendidik yang dengan bebas menuangkan metode mengajarnya di kelas, akan menyampaikan materi yang berkualitas sehingga siswa atau peserta didik antusias dalam menerima pelajaran dibandingkan dengan pendidik yang bekerja dengan target komersil.(Robert, 2006)

Selain itu proses-proses kreatif seseorang dapat terhampat karena faktor sosial seperti guru tidak bisa seenaknya saja mengajar dan melakukan pembelajaran itu melanggar humanitas positive siswa. Dalam dunia pendidikan juga sering berlaku demikian. Kreativitas pelajar ditekan dengan mencekoki berbagai macam hafalan, menjawab soal-soal dengan satu jalan yang sama, seringnya guru atau orang tua berkata awas, jangan dan melarang. Individu menjadi sangat takut berbuat salah, sehingga takut pula untuk mencoba. Hal ini menimbulkan ketidakpercayaan pada diri 
individu, mengurangi hasrat individu untuk mencoba hal-hal baru, karena takut akan penolakan atau ketidaksetujuan lingkungan sekitarnya.

Hal-hal terjadinya penghambat proses kreatifitas dan dipicu oleh situasi lingkungan pendidikan yang tidak tepat antara lain menurut (Mean, 2006) yaitu:

1. Jawaban yang benar, sistem pendidikan kebanyakan mengajarkan satu atau dua jawaban yang benar atas satu persoalan, kurang mengeksplorasi kemungkinan jawaban lain yang juga tidak salah.

2. Harus terdengar logis, semuanya harus dibuat sedemikian rupa sehingga tampak benar-benar masuk akal, sedikit sekali ruang tersisa untuk sebuah imajinasi. Logika memang diperlukan ketika mengevaluasi, tetapi perlu membebaskan pemikiran saat mencari pemecahan masalah.

3. Harus dapat dipraktekkan, sebelum sesuatu ide benar-benar bisa dilaksanakan tentu hal itu telah ada sebelumnya di benak dan di imajinasi pemikir. Ketika pendidik belum tahu pasti apakah suatu ide bisa terlaksana atau tidak, jangan berhenti

4. Ikuti aturan, banyak sekali arahan-arahan untuk selalu mengikuti aturan, jangan menjadi orang yang berbeda atau melakukan hal yang berbeda dari kebanyakan orang.

5. Tidak perlu bermain, salah satu cara belajar yang baik adalah dengan bermain. Tidak seperti di dunia nyata, dalam permainan saat kita menang berarti kita menang, tapi saat kita kalah kita belajar. Kita juga bermain dengan ide-ide sebelum ide tersebut tertuang menjadi produk yang nyata.

Kreativitas SDM yang bisa diterapakan dalam program FDS di pendidikan antara lain dengan active learning and educational implications penerapan belajar memiliki relevansi dengan guru-siswa, guru dan kebijakan, guru dan sekolah secara keseluruhan. Memiliki keterlibatan pribadi yang aktif (melibatkan kognisi dan perasaan peserta didik) adalah self-initiated (dorongan untuk belajar yang berasal dari dalam), sangat luas (mempengaruhi perilaku peserta didik, sikap, dan kepribadian) dandievaluasi aktif oleh peserta didik. Pendidik dan peserta didik memiliki potensi aktif untuk belajar dan semangat untuk mengajar dan belajar. Peserta didik menerima pemaknaan belajar karena mereka yakin bahwa hal itu akan meningkatkan mereka secara pribadi. Pembelajaran membutuhkan partisipasi aktif yang dikombinasikan dengan kritik diri dan evaluasi diri oleh peserta didik dan keyakinan bahwa belajar adalah penting. Tugas utama guru adalah bertindak sebagai fasilitator yang membentuk iklim kelas berorientasi pada proses belajar yang signifikan dan membantu siswa untuk memahami tujuan mereka. Dengan demikian, maka dapat disimpulkan bahwa fokusnya adalah membantu proses pembelajaran kreatif untuk menumbuhkan motivasi semua pihak dalam pendidikan. 
Terdapat empat sumber motivasi intrinsik, yaitu challenge, curiosity, control, dan fantasy. Pintrinch dan Schunk menunjukkan beberapa cara meningkatkan motivasi intrinsik, diantaranya adalah:

1. Challenge-Aktivitas yang menantang keterampilan siswa dapat membuat siswa termotivasi secara intrinsik. Aktivitas yang menantang adalah aktivitas yang kesulitannya berada dalam level sedang dan siswa dapat mengembangkan keterampilannya.

2. Curiosity-keingintahuan dapat difasilitasi oleh kegiatan yang membuat siswa mengemukakan informasi atau ide yang berbeda dengan pengetahuan atau kepercayaan mereka saat ini dan hal itu menimbulkan keterkejutan.

3. Control-aktivitas yang memberikan siswa kepercayaan bahwa merekalah yang mengontrol hasil akademis mereka dapat meningkatkan motivasi intrinsic.

4. Fantasy - fantasi, termasuk di dalamnya simulasi, memperkuat motivasi intrinsik.(Pintrich, P.R., 1996)

Implikasi pembelajaran dalam peningkatan mutu SDM dalam pengabdian ini dengan mempraktekan beberapa strategi yang dapat digunakan untuk menimbulkan motivasi intrinsik di kelas, diantaranya adalah:

1. Challange: tantang siswa dengan aktivitas yang memiliki tingkat kesulitan yang sedang. Yakinkan mereka bahwa mereka akan bosan dengan tugas-tugas yang mudah.

2. Curiosity: hadirkan ide-ide yang sedikit berbeda dari pengetahuan dan keyakinan yang telah siswa miliki. Masukkan kejutan dan inkonkruenitas ke dalam aktivitas kelas.

3. Control: izinkan siswa untuk memilih aktivitas dan mengungkapkan pendapat dalam memfrmulasikan aturan dan prosedur.

4. Fantasy: libatkan siswa dalam aktivitas-aktivitas yang membuatnya memiliki keyakinan, games, dan simulasi. Yakinkan mereka bahwa pembubuhan motivasi dalam aktivitas tersebut adalah tugas yang relevan dan tidak terlalu mengganggu.

Peningkatan mutu SDM dengan pembenahan pada kreativitas dan motivasi membantu peserta didik untuk mengatasi berbagai problem belajar. Salah satunya learned helplessness banyak menghinggapi peserta didik dengan masalah belajar di mana kepercayaan negatif berinteraksi secara resiprokal dengan keagagalan akademik. Untuk beberapa alasan, siswa yang gagal di sekolah mulai meragukan kemampuan belajar mereka dan melihat kesuksesan akademik sebagai sesuatu yang tidak dapat dikontrol. Kepercayaan ini menghasilkan rasa frustasi dan keinginan untuk menyerah dalam suatu tugas. Bila dibandingkan dengan pembelajar yang normal, siswa dengan masalah belajar memiliki ekspetasi kesuksesan yang lebih rendah, meereka menghakimi rendahnya kemampuan yang mereka miliki, dan menekankan kurangnya kemampuan 
sebagai penyebab kegagalan. Tujuan mereka sekolah adalah untuk menyelesaikan tugas dan menghindari penilaian negatif terhadap kemampuan mereka. mereka percaya bahwa kecerdasan adalah sesuatu yang tidak dapat berkembang lagi. Mereka menghindari tantangan. Sebaliknya, siswa yang berorientasi tujuan menampilkan pola prestasi yang melibatkan tugas. Mereka percaya bahwa kecerdasan dapat ditingkatkan, dan tujuan mereka bersekolah adalah untuk belajar dan menjadi lebih kompeten.

Siswa yang berorientasi tujuan dan siswa yang tidak berdaya seringkali memiliki kemampuan intelektual yang tidak berbeda. Meskipun siswa yang tidak berdaya memiliki kekurangan dalam keterampilan kognitif, hal tersebut bukanlah satu-satunya penyebab kegagalan. Tidak semua siswa dengan masalah belajar memasuki lingkaran ini, beberapa siswa menjadi mempunyai kepercayaan diri dan menampakkan pola atribusi yang positif. salah satu faktor yang penting adalah frekuensi kegagalan: siswa yang gagal dalam banyak mata pelajaran di sekolah lebih mudah mengalami learned helplessness. Oleh karena itu peran SDM yang bermutu dan memiliki kompetensi yang kreatif dan selalui memberikan motivasi pada siswa merupakan keterampilan penting dalam pembelajaran.

SDM dalam lingkup pendidikan termasuk guru dapat mengembangkan orientasi belajar yang produktif. Guru dapat menolong siswa mengubah keyakinan mereka tentang batasan kemampuan mereka dan kegunaannya. Memberikan siswa timbal balik yang menunjukkan bagaimana keterampilan mereka dapat diperbaiki, lalu dengan informasi menunjukkan bahwa usaha dapat membantu menghasilkan belajar, dapat meningkatkan efikasi diri dan motivasi siswa untuk memperbaiki keterampilan mereka lebih lanjut. Saran lainnya untuk menggunakan kolaborasi yang lain dari aktivitas siswa, orientasi pada tujuan dan keyakinan tentang kesuksesan tidak secara kuat dihubungkan dengan perasaan mampu. Perasaan mampu lebih baik dihubungkan dengan kepuasan dalam olahraga daripada dengan sekolah; pola sebaliknya diperoleh dari orientasi tugas. Cara yang lain untuk meningkatkan orientasi pada tujuan belajar adalah dengan menolong siswa mengadopsi tujuan belajar.

Guru memiliki keterampilan, strategi belajar yang baru, mengembangkan metode pemecahan masalah, dan seterusnya. Mereka juga dapat menegaskan kembali tujuan seperti melengkapi pekerjaan, dan memeriksa kembali pekerjaan. Pengembangan sumber daya manusia, salah satunya dengan peningkatan mutu pendidik ialah upaya dalam meningkatkan profesionalisme, kemampuan, ketrampilan, keahlian pendidik dalam memberikan pembelajaran yang optimal dan efektif. 


\section{KESIMPULAN DAN SARAN}

Berdasarkan hasil program pengabdian berbasis riset ini maka penulis menyimpulkan bahwa program workshop pembelajaran aktif dalam program full day school dalam meningkatkan mutu sumber daya manusia pada sebuah lembaga harus dilakukan secara kontinyu. Melalui workshop ini akan membekali guru-guru dalam melaksanakan program pembelajaran dengan efektif yang kemudian akan memberikan hasil yang baik terhadap prestasi akademik siswa, membantu menguatkan karakter, dan menumbuhkembangkan minat dan bakat setiap siswa. Melalui kegiatan Active Learning and Educational Implications, dalam program full day school akan membantu guru-siswa, guru dan kebijakan, guru dan sekolah secara keseluruhan. Siswa akan memiliki keterlibatan pribadi yang aktif, dorongan dari dalam untuk belajar, mempengaruhi perilaku peserta didik, sikap, kepribadian, dan dievaluasi aktif oleh siswa. Program workshop untuk mengembangkan mutu SDM sebaiknya dilakukan secara kontinyu sebab akan menjadikan Pendidik dan peserta didik memiliki potensi aktif untuk belajar dan semangat untuk mengajar dan belajar. Memiliki motivasi intrinsik, yaitu challenge, curiosity, control, dan fantasy.

\section{UCAPAN TERIMA KASIH}

Penulis mengucapkan terima Kasih kepada semua pihak yang membantu kegiatan pengabdian ini. Secara khusus penulis mengucapkan terima kasih kepada sekolah MI Al-Azhary Ajibarang Kab. Banyumas yang telah memberikan kesempatan kepada kami untuk melakukan pengabdian berbasis riset. Ucapakan terima kasih juga penulis sampaikan kepada IAIN Purwokerto telah memberikan dukungan berupa dana dan fasilitas dalam kegiatan pengabdian ini. Kegiatan ini dibiayai oleh DIPA IAIN Purwokerto 2019.

\section{DAFTAR PUSTAKA}

Baharun, H., \& Alawiyah, S. (2018). Pendidikan Full Day School Dalam Persfektif Epistimologi Muhammad `Abid Al-Jabiri. POTENSIA: Jurnal Kependidikan Islam, 4(6).

Ju`subaidi. (2012). Peningkatan Mutu Madrasah Melalui Modal Sosial. Nadwa Jurnal Pendidikan Islam, 6(272). Retrieved from http://dx.doi.org/10.21580/nw.2012.6.2.592

Kalangi, R. (2015). Pengembagan Sumber Daya Manusia dan Kinerja Aparat Sipil Negara di Kabupaten Kepulauan Sangihe Sulawesi Utara. Jurnal LPPM Bidang EkoSosBudkum, 2. Retrieved from https://ejournal.unsrat.ac.id/index.php/lppmekososbudkum/article/view/ 9296

Kobert, S. (1999). Handbook of Creativity. UK: Cambridge University Press. 
Kusumawati, N. (2017). Penerapan Metode Active Learning Tipe Team Quiz Untuk Meningkatkan Keaktifan Bertanya dan Kreatifitas Siswa pada Mata Pelajaran IPA Kelas V SDN Ronowijayan Ponorogo. Jurnal Bidang Pendidikan Dasar, 1(27). Retrieved from http://ejournal.unikama.ac.id/index.php/JBPD/article/view/1830/1442

Mean, L. A. (2006). On Creativity. Awakening the Creative Mind. Malaysia: Pelanduk Publication (M), Sdn Bhd.

Murti, A. S. (2016). Peningkatan Hasil Belajar PKN Kelas V Melalui Modul Active Learning (Tipe Role Reversal Question) SDN 4 Doplang Kecamatan Jati Kabupaten Blora. Jurnal Premiere Educandum, 6(192). Retrieved from http://doi.org/10.25273/pe.v6i02.811

Pintrich, P.R., S. (1996). Motivation in Education: Theory, Research, and Application. New Jersey: Prentice Hall.

Rahman, K. ., Ardiansyah, \& Marwazi. (2015). Rekrutmen Tenaga Pendidik dalam Peningkatan Mutu Madrasah Aliyah Negeri Insan Cendikia Jambi. Jurnal Pendidikan Islam, 9(30). Retrieved from http://dx.doi.org/10.21580/nw.2015.9.1.518

Robert, W. (2006). Creativity.Understanding Innovation in Problem Solving, Science, Invention and the Arts. New Jersey: John Wiley \& Sons.Inc. Hoboken.

Silbermen, M. (2014). Active Learning; 101 cara belajar siswa aktif. Bandung: Nuansa Cendikia. Sunaryo, M. (2017). Implementasi Model Pembelajaran Active Learning Tipe Pengadilan Majelis Hakim dalam Pembelajaran PJOK Materi Narkoba dan Pelecehan Seksual pada Siswa Kelas VI SDN Tanggulangin I. Jurnal Pendidikan Dan Pembelajaran Dasar, 9(85).

Syafrida, L. Y. (2017). Full Day School Sebagai Penguatan Pendidikan Karakter (Perspektif Psikologi Pendidikan Islam). FIKROTUNA. https://doi.org/10.32806/jf.v5i1.2945

Tamba, Wi. M., Manalu, H., Laurensia, \& Kariani, R. (2019). Menganalisa pengaruh Penerapan Full Day School Terhadap Minat Belajar Matematika Siswa di SMA Primbana Medan”. Jurnal Math Education Nusantara, 2(114). Retrieved from https://jurnal.pascaumnaw. ac.id/index.php/JMN/article/view/90

Winurini, S. (2016). Wacana Penerapan Full day School untuk Siswa SD dan SMP. Majalah Info Singkat Kesejahteraan Sosial, 8(9).

Yetti, E. (2016). Implementasi Model Pembelajaran Tari Pendidikan Untuk Meningkatkan Kecerdasan Kinestetik Anak Usia Dini Melalui Metode Pembelajaran Aktif. Jurnal Pendidikan Usia Dini, 10.388. Retrieved from http://pps.unj.ac.id/journal/jpud/article/ view/249 